\title{
DETERMINATION OF THE IN VITRO EFFECT OF LEMONGRASS (Cymbopogon flexuosus) OIL AGAINST FISH PATHOGENIC BACTERIA ISOLATED FROM CULTURED OLIVE FLOUNDER (Paralichthys olivaceus)
}

\author{
H.N.K.S. Pathirana, S.H.M.P. Wimalasena, B.C.J. De Silva, S. Hossain, Gang-Joon Heo* \\ Laboratory of Aquatic Animal Medicine, Veterinary Medical Center and College of Veterinary Medicine, Chungbuk National University, \\ Cheongju, 28644, Korea \\ ${ }^{*}$ Corresponding author, E-mail: gjheo@cbu.ac.kr
}

\begin{abstract}
The antibacterial activity of essential oil from lemongrass (Cymbopogon flexuosus) (LGO) was tested against strains of Edwardsiella tarda $(n=4)$, Photobacterium damselae $(n=1)$, Lactococcus garvieae $(n=1)$, Streptococcus iniae $(n=4)$ and $S$. parauberis $(n=4)$ isolated from cultured olive flounders in Korea. Disk diffusion assay, MIC (minimum inhibitory concentration) and MBC (minimum bactericidal concentration) tests showed the strains of Streptococcus spp. were the most sensitive. LGO was bactericidal (MBC/MIC=1-4) for all strains of L. garvieae, S. iniae and the FP5060 strain of E. tarda, and the FP5228, S527 and $S 1466$ strains of $S$. parauberis suggesting sensitivity to LGO. Gram-negative bacteria were less sensitive than Gram-positive bacteria. Since antibacterial activity of LGO was effective against fish pathogenic bacteria tested in this study, the use of LGO could be helpful in treating such bacterial infections in fish.
\end{abstract}

Key words: lemongrass oil; olive flounders; fish pathogenic bacteria; antimicrobial activity

\section{Introduction}

During the last decades, there has been a continuous growth in aquaculture industries in Korea. Infectious diseases cause high mortalities when appearing in intensive fish farming. The rapidly expanding aquaculture industry has suffered from heavy economiclosses due to bacterial pathogens, particularly infectious bacterial diseases including streptococcosis, lactococcosis and edwardsiellosis are major problems for olive

Received: 4 November 2018

Accepted for publication: 17 June 2019 flounder aquaculture in Korea $(1,2)$. Antibiotics are widely used to prevent bacterial infections in fish. However, continuous use of antibiotics leads to drug resistance and thereby to a reduced efficacy of the drugs (3). Antibiotics accumulate in the environment and fish and pose a potential risk to humans and to the environment (4). Thus, it is essential to develop antibacterial treatments that are made from natural substances.

For thousands of years, traditional medicines based on plants and plant extracts have been extensively utilized in humans and animals as remedies to control bacterial, viral, and fungal diseases (5). Natural products especially from 
plants have been investigated for their therapeutic and prophylactic effects on several fish diseases (6). Essential oils (EOs) are one kind of plant products which have been used for their aromatic, flavor, bactericidal, preservative and medicinal properties (7). Due to their safety and their recognized antimicrobial activity, there has been a considerable interest in plant essential oils to be used as possible alternatives to control bacterial infection in fish $(8,9)$.

Lemongrass (Cymbopogan citrates and $C$. flexuosus) is a plant belongs to the family Germineae, cultured in almost tropical and subtropical countries as a source of EO. Moreover, it is known to possess pharmacological properties, including antimicrobial and disinfectant functions $(10,11)$. The main active constituent of essential oil from lemongrass (LGO) is citral (65-95\%) (12). The effect of LGO has been studied against various microbes of environmental, clinical and food origin $(13,14)$

However, until now no study has been conducted to investigate the antimicrobial property of LGO against fish pathogenic bacteria isolated from olive flounder. Therefore, this study was carried out to examine the potential of LGO as an alternative to commercial antibiotics in aquaculture use.

\section{Materials and methods}

As test strains, five Gram-negative and nine Gram-positive bacterial strains isolated from Korean cultured olive flounder (Paralichthys olivaceus) were used. The Gram-negative strains were Edwardsiella tarda (FP5060, ED47, Yoshida and ED45), Photobacterium damselae (FP4101) and the Gram-positive strains were Lactococcus garvieae (FP5245), Streptococcus iniae (FP5228, S186, S530 and S131) and S. parauberis (FP5228, S124, S527 and S1466) obtained from Geyongsang National University (Jinju, Korea) and National Institute of Fisheries Science (Busan, Korea). The $100 \%$ pure lemongrass (C. flexuosus) oil (Aromarant Co. Ltd., Rottingen, Germany) was purified from the leaves of lemongrass grown in China.

The disc diffusion assay was conducted to detect the antimicrobial activity. Different concentrations of LGO $(1: 1,1: 2,1: 5$ and $1: 10 ; 1$ part of the LGO in respective parts of the methanolic solution) was dried on sterile disks (ADVANTEC ${ }^{\circledR}$, Japan), and each disc was placed on a Mueller Hinton agar (MBcell, Seoul, Korea) plate smeared with the test organism. Escherichia coli ATCC 25922 strain was used as the reference strain. Plates were incubated for $24 \mathrm{~h}$ at $27^{\circ} \mathrm{C}$ to determine the antimicrobial effect. The determination of MIC was done using broth micro dilution method with some modification using different concentrations of oil ( $5 \%$ DMSO was used to dissolve LGO). The MIC was measured after $24 \mathrm{~h}$ incubation and each test was repeated three times. In order to determine the $\mathrm{MBC}$, the culture medium from wells which have LGO concentration higher than MIC was smeared on separate Tryptic Soy Agar (TSA) (MBcell, Seoul, Korea) plates and incubated for $24 \mathrm{~h}$ at $27{ }^{\circ} \mathrm{C}$ (15). The concentration, at which no growth was observed on TSA plate, was determined as the MBC.

Antibiotic susceptibility was determined by disc diffusion method using OXOID ${ }^{\mathrm{TM}}$ antibiotic disks (Oxoid Co. Ltd., Seoul, Korea) mention in Table 2. Resistance profiles (resistant, intermediate or susceptible) were assigned using criteria described by Clinical and Laboratory Standards Institute (16). Each test was repeated three times.

\section{Results}

The Inhibition Zone diameters (IZDs) (mm) of Gram-negative bacteria ranged from 8 to $32 \mathrm{~mm}$ and the IZDs of Gram-positive bacteria ranged from 7 to $53 \mathrm{~mm}$ at 1:1 of LGO (Table 1). MIC of LGO for bacterial strains ranged from 0.016 to $0.5 \%(\mathrm{~V} / \mathrm{V})$ (Table 3). Mean MBC/MIC was 1 to 8 (Table 1).

The multiple antibiotic resistant index (MRI \%) of the isolates ranged between 0-57.1. E. tarda (ED45 and ED47) showed the highest MRI \% (57.1), followed by both L. garvieae (FP5245) and S. iniae (FP3287) (35.7) (Table 2).

\section{Discussion}

The results from the disk diffusion, MIC and MBC tests support the general characterization of Gram-positive and Gram-negative bacteria. Gram-negative bacteria are less susceptible to the inhibitory effects of essential oils compared Gram-positive bacteria, because they possess an outer membrane surrounding the cell wall which 
Table 1: Susceptibility pattern of lemon grass oil (LGO) against fish pathogenic bacteria

\begin{tabular}{|c|c|c|c|c|c|c|c|}
\hline \multirow{2}{*}{ Bacterial strain } & \multicolumn{4}{|c|}{$\begin{array}{l}\text { Inhibition zone }(\mathrm{mm}) \text { with different LGO } \\
\text { dilutions added on disc }\end{array}$} & \multirow{2}{*}{$\begin{array}{l}\text { MIC \% } \\
(\mathrm{V} / \mathrm{V})\end{array}$} & \multirow{2}{*}{$\begin{array}{l}\mathrm{MBC} \% \\
(\mathrm{~V} / \mathrm{V})\end{array}$} & \multirow{2}{*}{$\mathrm{MBC} / \mathrm{MIC}$} \\
\hline & $1: 1$ & $1: 2$ & $1: 5$ & $1: 10$ & & & \\
\hline $\begin{array}{l}\text { Photobacterium } \\
\text { damselae (FP4101) }\end{array}$ & 12 & 8 & 0 & 0 & 0.25 & 2 & 8 \\
\hline $\begin{array}{l}\text { Edwardsiella tarda } \\
\text { (FP5060) }\end{array}$ & 8 & 0 & 0 & 0 & 0.5 & 4 & 8 \\
\hline E. tarda (ED47) & 27 & 20 & 16 & 18 & 0.032 & 0.125 & 4 \\
\hline E. tarda (Yoshida) & 25 & 19 & 16 & 17 & 0.032 & 0.125 & 4 \\
\hline E. tarda (ED45) & 32 & 23 & 18 & 15 & 0.063 & 0.25 & 4 \\
\hline $\begin{array}{l}\text { Lactococcus garvieae } \\
\text { (FP5245) }\end{array}$ & 20 & 18 & 10 & 7 & 0.25 & 0.5 & 2 \\
\hline $\begin{array}{l}\text { Streptococcus iniae } \\
\text { (FP5228) }\end{array}$ & 22 & 19 & 11 & 8 & 0.125 & 0.25 & 2 \\
\hline S. iniae (S186) & 40 & 35 & 30 & 20 & 0.063 & 0.25 & 4 \\
\hline S. iniae (S530) & 38 & 32 & 30 & 24 & 0.125 & 0.5 & 4 \\
\hline S. iniae (S131) & 50 & 48 & 30 & 24 & 0.032 & 0.125 & 4 \\
\hline $\begin{array}{l}\text { Streptococcus parauberis } \\
\text { (FP5228) }\end{array}$ & 53 & 50 & 28 & 18 & 0.016 & 0.032 & 2 \\
\hline S. parauberis (S124) & 7 & 0 & 0 & 0 & 0.125 & 0.5 & 8 \\
\hline S. parauberis (S527) & 38 & 30 & 25 & 18 & 0.032 & 0.032 & 1 \\
\hline S. parauberis (S1466) & 45 & 35 & 26 & 19 & 0.016 & 0.063 & 4 \\
\hline
\end{tabular}


Table 2: Susceptibility pattern of lemon grass oil (LGO) against fish pathogenic bacteria

\begin{tabular}{|c|c|c|c|}
\hline \multirow{2}{*}{ Bacteria } & \multicolumn{2}{|c|}{ Antibiotics $^{\mathrm{a}}$} & \multirow{2}{*}{ MRI \% } \\
\hline & Sensitive & Resistant & \\
\hline \multirow[t]{2}{*}{ Photobacterium damselae (FP4101) } & AMX, AMP,CTX.CRO,TC,CHL, & VA & 7.14 \\
\hline & OFX, NAL, CN,IMI,SXT & & \\
\hline \multirow[t]{2}{*}{ Edwardsiella tarda (FP5060) } & AMX,CTX.CRO,TC,CHL, & AMP, CN, VA & 21.42 \\
\hline & OFX,NAL, IMI,SXT & & \\
\hline \multirow[t]{2}{*}{ E. tarda (ED47) } & AMX, CTX, CRO,IMI & AMP, TC, CHL, VA, NAL & 57.14 \\
\hline & & $\mathrm{SXT}, \mathrm{OFX}, \mathrm{CN}$ & \\
\hline \multirow[t]{2}{*}{ E. tarda (Yoshida) } & AMX, AMP,CTX.CRO,TC,CHL, & $\mathrm{VA}$ & 7.14 \\
\hline & OFX, NAL,CN,IMI, SXT & & \\
\hline \multirow[t]{2}{*}{ E. tarda (ED45) } & AMX, CTX, CRO, IMI & AMP,TC,CHL, VA, NAL, & 57.14 \\
\hline & & $\mathrm{SXT}, \mathrm{OFX}, \mathrm{CN}$ & \\
\hline Lactococcus garvieae (FP5245) & AMX, TC,DA, E, VA & AMP, CTX, CRO, CHL OFX & 35.71 \\
\hline Streptococcus iniae (FP3287) & AMX, TC, CHL, E, VA & AMP, CTX, CRO, DA, OFX & 35.71 \\
\hline \multirow[t]{2}{*}{ S. iniae (S186) } & AMX, AMP ,CTX, CRO, TC, CHL & 0 & 0 \\
\hline & E, DA, VA,OFX & & \\
\hline \multirow[t]{2}{*}{ S. iniae (S530) } & AMX, AMP ,CTX, CRO, TC, CHL & 0 & 0 \\
\hline & E, DA, VA, OFX & & \\
\hline \multirow[t]{2}{*}{ S. iniae (S131) } & AMX, AMP ,CTX, CRO, TC, CHL & 0 & 0 \\
\hline & $\mathrm{E}, \mathrm{DA}, \mathrm{VA}, \mathrm{OFX}$ & & \\
\hline \multirow[t]{2}{*}{ Streptococcus parauberis (FP5228) } & AMX, CTX, CRO, TC E, DA VA & AMP, CHL & 14.28 \\
\hline & OFX & & \\
\hline S. parauberis $(\mathrm{S} 124)$ & AMX, CTX,CRO,VA, CHL, OFX & AMP, TC, E, DA & 28.57 \\
\hline \multirow[t]{2}{*}{ S. parauberis (S527) } & AMX, CTX, CRO, TC, CHL & AMP & 7.14 \\
\hline & E, DA, VA, OFX & & \\
\hline \multirow[t]{2}{*}{ S. parauberis (S1466) } & AMX,CTX, CRO, TC, CHL & AMP, E & 14.28 \\
\hline & DA, VA, OFX & & \\
\hline
\end{tabular}

aAntibiotics- $\mathrm{AMP}=$ ampicillin $(10 \mu \mathrm{g}), \mathrm{CTX}=$ cefotaxime $(30 \mu \mathrm{g}), \mathrm{CRO}=$ ceftriaxone $(30 \mu \mathrm{g}), \mathrm{TC}=$ tetracycline $(15 \mu \mathrm{g}), \mathrm{CHL}=\mathrm{chloramphenicol}$ $(30 \mu \mathrm{g}), \mathrm{E}=$ erythromycin $(15 \mu \mathrm{g}), \mathrm{DA}=$ clindamycin $(10 \mu \mathrm{g}), \mathrm{VA}=\mathrm{vancomycin}(30 \mu \mathrm{g}), \mathrm{OFX}=\mathrm{ofloxacin}(5 \mu \mathrm{g}), \mathrm{NAL}=$ nalidixic acid $(30 \mu \mathrm{g})$, $\mathrm{CN}=$ gentamicin $(10 \mu \mathrm{g}), \mathrm{IMI}=$ imipenem $(10 \mu \mathrm{g})$ and $\mathrm{SXT}=$ trimethoprim-sulfamethoxazole $(25 \mu \mathrm{g}), \mathrm{AMX}=\mathrm{amoxicillin}(30 \mu \mathrm{g})$. 
Figure 1: Comparison of the effect of LGO against microbial strains. The graph depicts the bacteriostatic and bactericidal activity of LGO against fish pathogenic bacteria while showing the sensitive strains

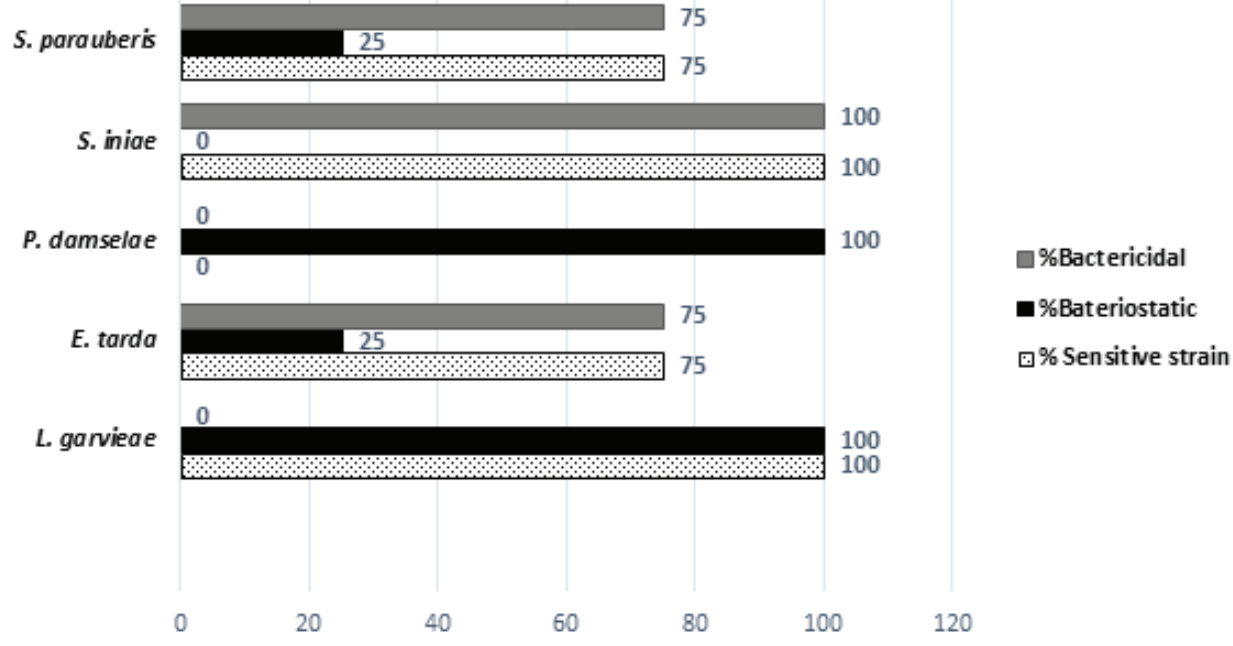

restricts the diffusion of hydrophobic compounds through its lipopolysaccharide covering (17). Previous studies have reported similar results of LGO where Micrococcus spp. and Streptococcus spp. as Gram-positive and E. tarda, E. coli and Proteus spp. as Gram-negative strains were tested $(13,18)$. In this study, Gram-positive (S. iniae, $S$. parauberis, $L$. garvieae) were also more sensitive than Gram-negative (E. tarda, P. damsalae).

All the strains were sensitive at every concentration of LGO except P. damsalae (FP4101), E. tarda (FP5060) and S. parauberis (S124) in disk diffusion test. The maximum effect of LGO was found at $1: 1$ concentration and the minimum effect was observed at 1:10 concentration of LGO. In the case of $P$. damsalae, it was sensitive for only $1: 1$ and $1: 2$ concentrations. Since the MIC value of $P$. damsalae was comparatively higher than other sensitive strains, it can be considered as less sensitive against LGO. E. tarda and S. parauberis strains with growth inhibition only at 1:1 concentration of LGO were also less sensitive. Meanwhile, S. parauberis (FP5228) was inhibited by the LGO with the largest zones of inhibition (Table 1).

Plant EOs can be classified into two categories, considering the $\mathrm{MBC} / \mathrm{MIC}$ ratio. The EOs which exhibit $\mathrm{MBC} / \mathrm{MIC}$ ratio $\leq 4$ are denoted as bactericidal for tested bacteria, while the EOs which demonstrate $\mathrm{MBC} / \mathrm{MIC}$ ratio >4 are represented as bacteriostatic (19). In the present study, LGO was bactericidal for all the sensitive strains while bacteriostatic for resistant strains. There was no any previous report about the MBC results of LGO against same bacteria tested. However, LGO demonstrated bactericidal activity at every concentration against eleven fish pathogenic bacteria in this study. There were both bactericidal and bacteriostatic strains in same bacterial species. A previous study reported cinnamon, bay, clove EOs were both bacteriostatic and bactericidal against different strains of L. monocytogenes (20). The test organisms were inhibited by LGO at comparatively low concentrations in MIC as compared to disk diffusion method (14). The results obtained by each of these methods differ due to many factors between assays including differences in microbial growth, exposure of microorganisms to the oil, the solubility of oil or oil components, etc $(14,21)$.

The bacteriostatic and bactericidal activity of LGO against fish pathogenic bacteria compared with the most sensitive strains showed $1 / 1$ (100\%) of L. garvieae, $3 / 4(75 \%)$ of $S$. parauberis, $4 / 4(100 \%)$ of S. iniae and 3/4 (75\%) of E. tarda were very sensitive to LGO. On the other hand, $1 / 1(100 \%)$ of P. damsalae, $1 / 4$ (25\%) of E. tarda and $1 / 4(25 \%)$ of $S$. parauberis (S124) were resistant (Figure 1). All microbes are not equally susceptible to LGO, although Streptococcocus spp. and E. tarda were comparatively more susceptible to LGO (22).

All the test strains showed the difference in their sensitivity against different antibiotics (Table 2). The comparative effects of LGO and the standard antibiotic discs on the various test organisms are demonstrable indications of the oil as an antibacterial agent. A similar kind of observation was reported with some selected pathogenic bacteria and had suggested that 
the test organisms particularly Gram negative were found to be more susceptible to LGO than standard antibiotics (14).

Nowadays, treatment of fish for various infections poses a serious problem in Korea and many regions of the world (2). The present study established that LGO has potential antibacterial property, and is a good candidate for further research to develop a new antibacterial drug against fish pathogenic bacteria. Moreover, in order to gain more perceptivity into the application of LGO for fish bacterial diseases, the stability and safety of LGO in the aquatic environment should also be further investigated.

\section{Acknowledgements}

The authors declare no conflict of interests. Authors are thankful to Professor Tae-Sung Jung of Institute of Animal Medicine, College of Veterinary Medicine, Gyeongsang National University (Jinju, Korea) and National Institute of Fisheries Science (Busan, Korea) for providing the bacterial strains used in this study.

\section{References}

1. Jeong YU, Subramania D, Yeoung-Hwan J, et al. Protective efficiency of an inactivated vaccine against Streptococcus iniae in olive flounder, Paralichthys olivaceus. Arch Pol Fish 2016; 24: 23-32.

2. Lim JW, Jung MH, Jung SJ, Kim DH, Park $\mathrm{KH}$, Kang SY. The efficacy of amoxicillin sodium against streptococcosis in cultured olive flounder Paralichthys olivaceus and its pharmacokinetics. J Vet Pharmacol Therap 2016; 40: 77-87.

3. Wei LS, Wee W. Chemical composition and antimicrobial activity of Cymbopogon nardus citronella essential oil against systemic bacteria of aquatic animals. Iran J Microbiol 2013; 5: $147-$ 52 .

4. Akbar P. In vitro inhibitory activity of the leaf methanol extract of green tea (Camellia sinensis) against Lactococcus garvieae and Aeromonas hydrophila isolated of Rainbow trout (Oncorhynchus mykiss). Adv Microbiol 2014; 4: 829-34.

5. Lovkova MY, Buzuk GN, Sokolova SM, Kliment'eva NI. Chemical features of medicinal plants: review. Appl Biochem Microbiol 2001; 37: 229-37.
6. Rattanachaikunsopon P, Phumkhachorn P. Protective effect of clove oil-supplemented fish diets on experimental Lactococcus garvieae infection in Tilapia. Biosci Biotech Biochem 2009; 73: 2085-9.

7. Burt S. Essential oils: their antibacterial properties and potential applications in foods-a review. Int J Food Microbiol 2004; 94: 223-53.

8. Al-Hajj NQM, Algabr MN, Raza H, et al. Antibacterial activities of the essential oils of some aromatic medicinal plants to control pathogenic bacteria and extend the shelf-life of seafood. Turk J Fish Aquat Sci 2017; 17: 181-91.

9. Park JW, Wendt M, Heo GJ. Antimicrobial activity of essential oil of Eucalyptus globulus against fish pathogenic bacteria. Lab Anim Res 2016; 32: 87-90.

10. Hanaa ARM, Sallam YI, El-Leithy AS, Aly SE. Lemongrass (Cymbopogon citratus) essential oil as affected by drying methods. Ann Agric Sci 2012; 57: 113-6.

11. Jeong MR, Park BP, Kim DH, Jang YS, Jeong HS, Choi HS. Essential oil prepared from Cymbopogon citrates exerted an antimicrobial activity against plant pathogenic and medical microorganisms. Micobiology 2009; 37: 48-52.

12. Adukwu EC, Bowles M, Edwards-Jones $\mathrm{V}$, Bone $\mathrm{H}$. Antimicrobial activity, cytotoxicity and chemical analysis of lemongrass essential oil (Cymbopogon flexuosus) and pure citral. Appl Microbiol Biotechnol 2016; 100: 9619-27.

13. Adukwu EC, Allen SCH, Phillips CA. The anti-biofilm activity of lemongrass (Cymbopogon flexuosus) and grapefruit (Citrus paradisi) essential oils against five strains of Staphylococcus aureus. J Appl Microbiol 2012; 113: 1217-27.

14. Naik MI, Fomda BA, Jaykumar E, Bhat JA. Antibacterial activity of lemongrass (Cymbopogon citratus) oil against some selected pathogenic bacterias. Asian Pacific J Trop Med 2010; 2010: 535-8.

15. Hammer KA, Carson CF, Riley TV. Antimicrobial activity of essential oils and other plant extracts. J Appl Microbiol 1999; 86: 985-90.

16. CLSI. Performance standards for antimicrobial susceptibility testing: 24th informational supplement: CLSI M100-S24. Wayne, USA : Clinical and Laboratory Standards Institute (CLSI), 2014.

17. Turker H, Yildirim AB, Karakas FP. Sensitivity of bacteria isolated from fish to some medicinal plants. Turk J Fish Aquat Sci 2009; 9: 181-6. 
18. Marino M, Bersani C, Comi G. Impedance measurements to study the antimicrobial activity of essential oils from Lamiaceae and Compositae. Int J Food Microbiol 2016; 7: 187-95.

19. Koné WM, Atindehou KK, Terreaux C, Hostettmann K, Traoré D, Dosso M. Traditional medicine in north cote-d'ivoire: screening of 50 medicinal plants for antibacterial activity. J Ethnopharmacol 2004; 93: 43-9.

20. Smith-Palmer A, Stewart J, Fyfe L. Antimicrobial properties of plant essential oils and essences against five important food-borne pathogens. Lett Appl Microbiol 1998; 26: 118-22.
21. Khan MY, Gupta P, Singh VK, Yadav S, Verma VK. Cymbopogon Citrates oil showing antimicrobial activity against microbes of environmental, clinical and food origin. Asian J Pharm Technol 2013; 3: 67-72.

22. Singh BR, Singh V, Singh RK, Ebibeni N. Antimicrobial activity of lemongrass (Cymbopogon citratus) oil against microbes of environmental, clinical and food origin. Int Res Pharm Pharmacol $2011 ; 1: 228-36$.

\title{
IN VITRO UČINEK OLJA LIMONSKE TRAVE (Cymbopogon flexuosus) PROTI RIBJI PATOGENI BAKTERIJI, IZOLIRANI IZ GOJENEGA MORSKEGA LISTA (Paralichthys olivaceus)
}

\author{
H.N.K.S. Pathirana, S.H.M.P.Wimalasena, B.C.J.De Silva, S. Hossain, G.J. Heo
}

Povzetek: Protibakterijsko delovanje eteričnega olja limonske trave (Cymbopogon flexuosus; LGO) je bilo preizkušeno glede njihovega delovanja proti sevom bakterij Edwardsiella tarda $(n=4)$, Photobacterium damselae $(n=1)$, Lactococcus garvieae $(n=1)$, Streptococcus iniae $(n=4)$ in S. parauberis $(n=4)$ pridobljenih iz gojenih morskih listov v Koreji. Difuzijska metoda z diskom ter testi MIC (najmanjša zaviralna koncentracija) in MBC (najmanjša baktericidna koncentracija) so pokazali, da so bili sevi Streptococcus spp. najbolj občutljivi. LGO je imel baktericidno delovanje (MBC / MIC = 1-4) na vse seve L. Garvieae in S. Iniae ter na seva FP5060 in FP5228 E. Tarda in seva S527 in S1466 S. parauberis. Gram-negativne bakterije so bile manj občutljive od gram-pozitivnih bakterij. Ker je bilo antibakterijsko delovanje LGO učinkovito proti ribjim patogenim bakterijam, preizkušenim v tej študiji, bi lahko uporaba LGO pomagala prizdravljenju tovrstnih bakterijskih okužb pri ribah.

Ključne besede: olje limonske trave; morski list; patogene bakterije rib; protimikrobno delovanje 